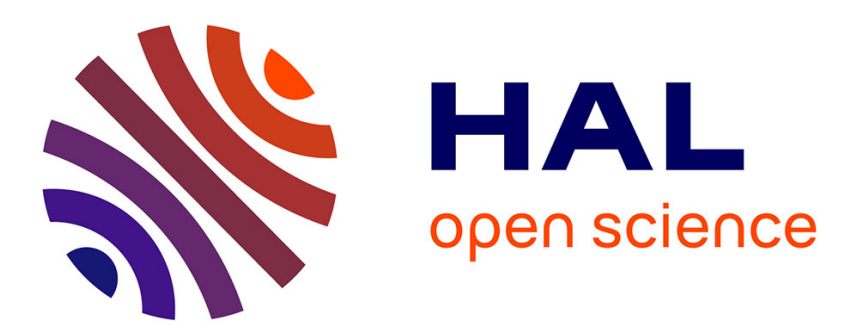

\title{
Evaluating the success of managed realignment for the restoration of salt marshes: Lessons from invertebrate communities
}

Julien Petillon, Simon Potier, Alexandre Carpentier, Angus Garbutt

\section{- To cite this version:}

Julien Petillon, Simon Potier, Alexandre Carpentier, Angus Garbutt. Evaluating the success of managed realignment for the restoration of salt marshes: Lessons from invertebrate communities. Ecological Engineering, 2014, 69, pp.70 - 75. 10.1016/j.ecoleng.2014.03.085 . hal-01061276

\section{HAL Id: hal-01061276 \\ https://hal.science/hal-01061276}

Submitted on 5 Sep 2014

HAL is a multi-disciplinary open access archive for the deposit and dissemination of scientific research documents, whether they are published or not. The documents may come from teaching and research institutions in France or abroad, or from public or private research centers.
L'archive ouverte pluridisciplinaire HAL, est destinée au dépôt et à la diffusion de documents scientifiques de niveau recherche, publiés ou non, émanant des établissements d'enseignement et de recherche français ou étrangers, des laboratoires publics ou privés. 
Evaluating the success of managed realignment for the restoration of salt marshes: lessons from invertebrate communities

Julien Pétillon ${ }^{\mathrm{a},{ }^{*}}$, Simon Potier ${ }^{\mathrm{a}}$, Alexandre Carpentier ${ }^{\mathrm{a}}$, Angus Garbutt ${ }^{\mathrm{b}}$

${ }^{a}$ Université de Rennes 1, Rennes, France

${ }^{\mathrm{b}}$ NERC Centre for Ecology and Hydrology, Bangor, UK

"Corresponding author at: Université de Rennes 1, EA7316, 263 Avenue du Général Leclerc,

CS 74205, 35042 Rennes Cedex, France. Tel.: +33 223236 51; fax: +33 22323538.

E-mail address: julien.petillon@ univ-rennes1.fr (J. Pétillon). 


\section{ABSTRACT}

Studying successional processes and related factors in salt marshes encompasses both fundamental (community structuration) and applied (biodiversity conservation and restoration) issues. Current managed realignment projects and sites where, in the past, large storm events led to breaches in embankments create unique experimental conditions for such challenges by re-instating tidal inundation and salt-marsh development. We conducted a pairmatched approach using natural and recreated (either accidentally or managed) salt marshes and studied changes in invertebrate communities over time during a field experiment (Essex, UK). Trophic guild was assigned to all invertebrates, and detailed analyses conducted on most abundant (amphipods, Orchestia sp., 9666 individuals) and diversified (spiders, 43 species) groups. A total of 27,180 invertebrates (almost all arthropods: $99 \%$ of specimens) was collected in 2005. The conservation equivalency was achieved quickly (which was shown here with spider assemblages), but that did not translate into a complete functional equivalency. Indeed neither the structure of trophic guilds, nor the potential role of marine enrichment and fish nursery, estimated through the population size of amphipods, were achieved by managed realignments. We finally argue that the study of invertebrates brings information complementary to those brought by plants, and underline that functional and conservation equivalency have to be assessed separately.

Key-words: restoration; intertidal systems; macro-arthropods; Essex 


\section{Introduction}

Salt marshes are intertidal ecosystems, located at the interface between marine and terrestrial systems. They are among the most surface-restricted habitats in the world, dramatically declining in Europe where they currently have a high interest in terms of nature conservation, especially in relation to global change and sea-level rise. Salt marshes make excellent systems to demonstrate both fundamental and applied ecological principles. They have strong directional and predictable physical and ecological gradients and a limited species pool of specialist fauna and flora. Salt-marsh dynamics are driven by the frequency of tidal inundation and sediment supply. When there is net accumulation of sediment, vegetation communities respond driving succession, defined as a non-seasonal, directional pattern of plant species change (e.g. Adam 1990). Succession mechanisms have been extensively studied for plants. Without the impact of herbivores, salt marshes move towards typical late successional stages over time (Kuijper et al. 2004). Grazing by both small herbivores (mainly hare and geese) and large herbivores (i.e., cattle, sheep) retards succession. This general scheme is in reality much more complex and factors acting on plant succession are numerous and produce many feedbacks (Olff et al., 1997). Although complex, there has been much research carried out on plant assemblages along successional schemes, and this is in contrast with work on invertebrates.

Self-sustaining plant communities are often a primary goal of habitat creation efforts as they can perform biological and economically desirable functions within wetland ecosystems. There is little evidence however that shows similar trends in assembly rule between plants and other groups. Dispersal is generally not considered to be a limiting factor for plant reassembly, due to the general connectivity of the system through tidal flooding (Wolters et al., 2005; Erfanzadeh et al., 2010). In contrast, dispersal has been proved to be a critical 
element in arthropod assemblage structuring (e.g. Varet et al. 2013), and few comparisons between plants and arthropod succession can be made in European salt marshes. Late successional stages of vegetation development are characterised by low diversity Elytrigia atherica swards (Kuijper et al., 2004). Conversely, late successional spider communities generally show an increase in diversity and in density (Pétillon et al., 2005). Mechanisms and processes of succession in salt marshes thus largely differ between plants and other groups of animals.

Current intertidal habitat creation schemes and sites where, in the past, large storm events led to accidental breaches in embankments resulted in the re-instatement of tidal inundation and salt-marsh development have created unique experimental conditions for studying salt-marsh successions, and critical study sites for restoration ecology (e.g. Teal and Weishar, 2005). 'Historic' sites can be used as analogues for modern day managed realignment and, along with current managed realignment sites, give space for time examples of saltmarsh development on former agricultural land (Hinkle and Mitsch, 2005).

One recent study, based on vegetation analysis, showed that restoration of tidal inundation to former agricultural land remains insufficient measures to ensure "equivalent biological characteristics" to natural reference sites (Mossman et al., 2012). We conducted a similar survey at a subset of the same sites (pair-matched natural and recreated, either accidentally or by managed realignment, salt marshes) on invertebrate communities in a field experiment in UK, and assessed both the conservation (condition at a given time) and functional (proxy of process over time) equivalencies (sensu Zedler and Lindig-Cisneros, 2000) between recreated and natural salt marshes.

The conservation value of salt marshes was estimated through two classical conservation criteria, i.e. abundance of halophilic species and species richness. In salt marshes spiders are the most abundant and diversified of terrestrial macro-arthropods, and host some specialist, 
halophilic, species, with behavioural and physiological adaptations to flood and saline stress (e.g. Foucreau et al., 2012). Trophic guilds were used to evaluate the functional restoration of invertebrate communities (e.g. Gratton and Denno, 2005). One more particular focus was done on amphipods because of their role as decomposers (thereby controlling the magnitude of organic matter outwelling toward marine systems) and as main food item for juveniles of several fish species (nursery function of salt marshes: e.g. Laffaille et al., 2005).

\section{Material and Methods}

\subsection{Study sites}

We selected 20 study sites varying in their restoration age (including 4 managed realigned sites coded MR and aged 3 to 15 years, and 6 accidentally realigned sites coded AR and aged from 52 to 107 years), allowing 11 comparisons natural (coded Reference) /recreated salt marshes (for a full description of the sites, see Garbutt and Wolters, 2008). We were not interested here in the comparison AR vs MR per se, but instead in assessing the influence of age since restoration on the recolonization process of salt-marsh invertebrates. Sites were therefore considered as forming a continuum over time (chrono-sequence approach). Natural and recreated sites had 100m-study transect at the same elevation, and located along the Blackwater Estuary (Essex, UK). All MR/AR sites were under agricultural use prior to reexposure to tidal flooding. The Essex marshes are amongst the oldest in the UK, probably developed from the Holocene period after the last ice age.

\subsection{Sampling design}

Pitfall traps $(80 \mathrm{~mm}$ in diameter and $105 \mathrm{~mm}$ deep), containing a solution of 50:50 water/ethylene-glycol, were inserted into the ground 10 meters apart to avoid interference and 
pseudo-replication (Topping and Sunderland, 1992), ensuring that the rim of the trap was at ground level. Ten pitfall traps were set along each transect and were active 2 times 3 -days (i.e. when tides permitted sampling) during June 2005 . We used a large number of traps $(220 * 2$ sessions in total) to increase spatially the sampling effort. Thirty sweep net samples were taken along each of the three $30 \mathrm{~m}$ lengths of the sampling transect (i.e. approximately 1 sweep/m) to give three samples per transect. Four 20 second suction samples by Vortis (diameter: $16 \mathrm{~cm}$ ) were taken within a $1 \mathrm{~m}^{2}$ area, centred on the pitfall traps. The three $1 \mathrm{~m}^{2}$ sampling areas were selected by randomisation of the number of pitfall traps (from1 to 10). Both sweep netting and vortexing were carried out during August 2005 (at low tide). Percentage cover of each plant species (and bare soil) and litter depth (to the nearest $\mathrm{mm}$ ) were finally estimated within $1 \mathrm{~m}^{2}$ around each trap at the same time.

\subsection{Data analysis}

Data from pitfall traps were used to study ground-dwelling spider assemblages. The target species were halophilic species, defined by their preference or exclusive presence in salt marsh habitats, which can be assessed using distribution maps and habitat preferences (Pétillon et al., 2005). The fraction of spider species pool was calculated for the total number of individuals and species richness (of all species and that of halophilic species, for the two parameters), and analysed over time using Spearman's rank correlation. The fraction of the population pool was then calculated for the three most abundant spider species (here more than 80 individuals) and analysed over time using Spearman's rank correlation. ANOSIM (using Bray-Curtis similarity index) and Non-metric Multi-dimensional Scaling (NMDS) were also used to test for differences in spider assemblages among salt-marsh types.

Samples from individual sites were grouped by marsh types into MR, AR and reference marsh data sets. All invertebrates collected by the three sampling methods were assigned to trophic 
guilds. For amphipods, only data from pitfall traps were used because the activity-densities of Orchestia sp. obtained through this method can be used a proxy of biomasses of that arthropod (Mantzouki et al,. 2012). Abundances of amphipods, number of individuals per guild and habitat characteristics were compared among classes of habitat with GLMM (Generalized Linear Mixed Model). Fixed effect was the marsh type (MR, AR, Reference) and the random effect was the study sites. In the absence of significant random effect, the statistic used was a GLM (Generelized Linear Model). Indval was calculated to estimate the fidelity of plant species to the different types of habitats (i.e. natural salt marshes vs polders, AR vs MR; Dufrêne and Legendre, 1997; 1000 permutations).

All analyses were performed in R 2.14.2 (R Development Core Team 2012, see the full list of packages in ESM: Table A.1). Throughout the paper, means are presented \pm se and significance was assumed for $\mathrm{P}<0.05$.

\section{Results}

A total of 27180 invertebrates was sampled, of which 6418 were collected by Vortis, 5915 by sweep net and 14847 by pitfall trap. Amphipods and spiders constituted the most abundant and diversified groups of macro-arthropods respectively, with 9666 individuals (Orchestia sp.) and 42 spider species (see taxonomic list in ESM: Table A.2).

\subsection{Conservation equivalency}

Spider species richness significantly decreased over time since reintroduction of tidal flooding (Spearman: $\mathrm{P}<0.001$; Rho=-0.34; Fig. 1a). No correlation was found between time since restoration and fraction of halophilic species pool (Spearman: $\mathrm{P}=0.401$; Fig.1b), fraction of activity-density of all species (Spearman: $\mathrm{P}=0.183$; Fig.1c) and fraction of activity-density of 
halophilic species (Spearman: $\mathrm{P}=0.205$; Fig.1d). Spider species composition of MR sites was significantly different from that of reference and accidentally realigned sites (ANOSIM, $\mathrm{R}=0.265, \mathrm{P}<0.001$ and $\mathrm{R}=0.227, \mathrm{P}<0.001$, respectively; see also the NMDS in Fig.A.1 of ESM). The difference in spider species composition between AR and Reference sites was less obvious ( $\mathrm{R}=0.029, \mathrm{P}<0.001)$. Abundance of Pardosa prativaga (Fig. 2b; Spearman: $\mathrm{P}=0.033$, Rho=-0.20) and Pardosa purbeckensis (Fig. 2c; Spearman: $\mathrm{P}<0.001$, Rho=-0.31) decreased over time while that of Pirata piraticus increased in the meantime (Fig. 2a; Spearman: $\mathrm{P}<0.001, \mathrm{Rho}=0.37)$.

\subsection{Functional equivalency}

Abundance of predator and phytophagous species decreased from managed realignment to reference salt marshes (Fig. 3a, c). The number of polyphagous arthropods was higher in managed realignment salt marsh compared to accidental one, with an intermediate value for reference salt marsh (Fig. 3b). Abundance of detritivores was significantly higher in reference sites, with a significantly lower mean in MR compared to AR sites (Fig. 3d). Vegetation height decreased from managed realignment to reference salt marsh (Fig. 3e). Litter depth significantly differed between the three classes of salt marsh, with a maximum mean in AR sites and a minimum in MR sites (Fig. 3f). Abundance of Orchestia gammarella increased from managed realignements to reference sites (Fig. 4). Several plant species, Atriplex portulacoides, Bostrychia scorpioides, Cochlearia officinalis, Limonium vulgare, Puccinellia maritima, Spergularia media and Triglochin maritima, were indicator of reference salt marshes $\quad$ IndVal=64.75, IndVal=19.13, IndVal=28.00, IndVal=29.08, IndVal=56.41, IndVal=18.84, and IndVal=21.99, respectively; $\mathrm{P}=0.017$ ) compared to $\mathrm{MR}$ and $\mathrm{AR}$ sites. Only Spartina anglica was characteristic of all realigned sites (IndVal=37.40, P=0.017), but it was significant in MR sites ( $\mathrm{IndVal}=32.82, \mathrm{P}=0.017$ ) only (i.e. not in AR sites alone). 


\section{Discussion}

The conservation equivalency between managed realigned, accidentally realigned and reference sites was reached for spiders, after only a few (3-15) years of succession. All conservation parameters were similar between sites, except the diversity of spider species which decreased over time. This is in contrast with plants, for which managed realignment did not lead to the restoration of equivalent halophytic communities (Mossman et al., 2012), with high percentages of target species lacking (Garbutt and Wolters, 2008). The same pattern is observed in this study with the only characteristic plant species of restored (either by managed realignment or accidentally, the pioneer and invasive Spartina anglica) sites different from typical, target, species from natural salt marshes (mainly Atriplex portulacoides). The great long-distance dispersal abilities of spiders likely explain the early colonization of realigned sites by halophilic species, with a possible fast colonization of most sites from the regional species pool (Pétillon and Garbutt, 2008; Cristofoli et al., 2010). These dispersal capacities are probably higher than those of ground beetles (Varet et al., 2013), group in which incomplete restoration has been shown after dozen of years in littoral habitats (Desender et al., 2007). Studying recolonization of restored sites by ground beetles could therefore be interesting in the future, although they are much less abundant and diversified than spiders there (number of adults and species 5 and 4 times lower respectively: Pétillon and Garbutt, unpublished data). In salt marshes, long-distance dispersal of certain ground beetles can be reduced in old and large sites due to an increase in the percentage of apterous specimens (Desender et al., 1998). Spiders are also less dependent on soil properties than plants. The role of habitat structure in itself has indeed been proved repetitively in determining species richness of spiders (more than age of habitats for example: Hurd and Fagan, 1992), and this 
parameter is overall constant in the sites we studied (Garbutt et al., 2006). In contrast, enhanced $\mathrm{pH}$ and salinity and reduced oxygenation and porosity are likely to delay plant succession (Mossman et al., 2012), and also to reduce litter decomposition (as suggested by both the low number of detritivores and a deep litter layer in restored sites). Although the species richness and total number of individuals were overall constant over time, assemblage composition significantly varied through years, tending to be closer to assemblages from natural salt marshes over time from restoration (results from Anosim). Exclusive competition probably occurred between spider species, as suggested here by the opposite population patterns over time of the three dominant lycosid species (also stressed in Pétillon \& Garbutt 2008).

Using a space-for-time approach to saltmarsh development upon re-exposure to tidal flooding, we deduce a clear shift in functional equivalency from managed realigned to natural salt marshes through accidentally realigned sites, and most of the parameters studied exhibited a graduate, either increasing or decreasing response to time. Our main results fit well to the assembly rule found by Schrama et al. (2012) in an European salt-marsh, through a chronosequence of 100 years. They indeed described that, at the beginning of the succession, most incoming fluxes of organic matter and decomposers are mostly marine, whereas the importance of terrestrial matter and invertebrates increases over time. Yet, we did not observe an increase of vegetation height over time, but the inverse, mainly due to the dominance of Spartina anglica in early stages. The number of amphipods, even accounting for the increase between managed realigned and accidentally realigned sites, was much lower (more than 3 times) in restored than in natural salt marshes. This can be explained by reduced content of organic matter (Garbutt et al. 2006) and could have strong implications for the food provisioning ability of regenerated marshes for fish species, and also a likely reduced export of organic matter toward marine adjacent ecosystems (as amphipods represent key-component 
in the decomposition of organic matter: Graça et al. 2000).

As a conclusion, this study underlines the necessity to study both conservation and functional traits of restored systems, and to multiply monitoring with different model groups even when they are time-costly to sample and identify. Indeed, conservation equivalency can be quickly achieved (which is shown here with spider assemblages), but that does not translate into a complete functional equivalency (which was also stressed by Zedler and Lindig-Cisneros, 2000 for the restoration of salt marshes in USA). In this study, neither the salt-marsh trophic structure, nor the potential role of marine enrichment and fish nursery (estimated through the population size of amphipods) were achieved by managed realignments. We finally urge the scientific community to consider managed realignments as excellent study systems for applied and fundamental purpose (assuming a long chrono-sequence), with a particular attention to less-studied taxa like terrestrial arthropods.

\section{Acknowledgments}

We thank Peter Merett for the identification of problematic specimens, Pete Nuttall and Sarah Hulmes for sorting the samples for further identification, Boris Leroy, Maxime Hervé and two anonymous referees for constructive comments.

\section{Supporting information}

Electronic Supplementary Material may be found in the online version of this article under the DOI reference:

Table A.1. List of the packages used for statistical analyses.

Table A.2. Taxonomic list of the spider species (bold: halophilic species). 
Fig. A.1. Non-metric multi-dimensional scaling ordination of spider assemblages from reference, accidentally and managed realigned saltmarshes.

\section{References}

Adam, P., 1990. Saltmarsh ecology. Cambridge University Press, Cambridge.

Cristofoli, S., Mahy, G., Kekenbosch, R., Lambeets, K., 2010. Spider communities as evaluation tools for wet heathland restoration. Ecol. Indic. 10, 773-780.

Desender, K., Backeljau, T., Delhaye, K., De Meester, L., 1998. Age and size of European saltmarshes and the population genetic consequences for ground beetles. Oecologia 114, 503-513.

Desender, K., Maelfait, J.-P., Baert, L., 2007. Ground beetles as 'early warning-indicators' in restored salt marshes and dune slacks. Coastline Rep. 7, 25-39.

Dufrêne, M., Legendre, P., 1997. Species assemblages and indicator species: the need for a flexible asymmetrical approach. Ecol. Monogr. 67, 345-366.

Erfanzadeh, R., Garbutt, A., Pétillon, J., Maelfait, J.-P., Hoffmann, M., 2010. Factors affecting the success of early salt-marsh colonizers: seed availability rather than site suitability and dispersal traits. Plant Ecol. 206, 335-347.

Foucreau, N., Renault, D., Lugan, R., Hidalgo, K., Pétillon, J. 2012. Effects of diet and salinity on the survival, egg laying and metabolic fingerprints of the ground-dwelling spider Arctosa fulvolineata (Araneae, Lycosidae). Comp. Biochem. Physiol. Mol. Integr. Physiol. 163, 388-395.

Garbutt, R.A., Reading, C.J., Wolters, M., Gray, A.J., Rothery, P., 2006. Monitoring the development of intertidal habitats on former agricultural land after the managed realignment of coastal defences at Tollesbury, Essex, UK. Mar. Pollut. Bull. 53, 155-164.

Garbutt, R.A., Wolters, M., 2008. The natural regeneration of salt marsh on formerly 
reclaimed land. Appl. Veg. Sci. 11, 335-344.

Graça, M.A., Newell, S.Y., Kneib, R.T., 2000. Grazing rates of organic matter and living fungal biomass of decaying Spartina alteniflora by three species of salt-marsh invertebrates. Mar. Biol., 136, 281-289.

Gratton, C., Denno, R.F. 2005. Restoration of arthropod assemblages in a Spartina salt marsh following removal of the invasive plant Phragmites australis. Restor. Ecol. 13, 358-372.

Hinkle, R.L., Mitsch, W.J., 2005. Salt marsh vegetation recovery at salt hay farm wetland restoration sites on Delaware Bay. Ecol. Eng. 25, 240-251.

Hurd, L.E., Fagan, W.F., 1992. Cursorial spiders and succession: age or habitat structure? Oecologia 92, 215-221.

Kuijper, D.P.J., Nijhoff, D.J., Bakker, J.P., 2004. Herbivory and competition slow down invasion of a tall grass along a productivity gradient. Oecologia 141, 452-459.

Laffaille, P., Pétillon, J., Parlier, E., Valéry, L., Aubert, C., Ysnel, F., Radureau, A., Feunteun, E., Lefeuvre, J.-C., 2005. Does the invasive plant Elymus athericus modify fish diet in tidal salt marshes? Estuar. Coast. Shelf S. 65, 739-746.

Mantzouki, E., Ysnel, F., Carpentier, A., Pétillon, J., 2012. Accuracy of pitfall traps for monitoring populations of the amphipod Orchestia gammarella (Pallas 1766) in a salt marsh. Estuar. Coast. Shelf S.113, 314-316.

Mossman, H.L., Davy, A.J., Grant, A., 2012. Does managed coastal realignment create saltmarshes with 'equivalent biological characteristics' to natural reference sites? J. Appl. Ecol. 49, 1446-1456.

Olff H., De Leeuw J., Bakker J.P., Platerink R.J., Van Wijnen H.J., De Munck, W., 1997. Vegetation succession and herbivory in a salt marsh: changes induced by sea level rise and silt deposition along an elevational gradient. J. Ecol. 85, 799-814.

Pétillon, J., Garbutt, A., 2008. Success of managed realignment for the restoration of salt- 
marsh biodiversity: preliminary results on ground-active spiders. J. Arachnol. 36, 388393.

Pétillon, J., Ysnel, F., Canard, A., Lefeuvre, J.-C., 2005. Impact of an invasive plant (Elymus athericus) on the conservation value of tidal salt marshes in western France and implications for management: responses of spider populations. Biol. Conserv. 126, 103117.

Schrama, M., Berg, M., Olff, H., 2012. Ecosystem assembly rules: the interplay of green and brown webs during salt marsh succession. Ecology 93, 2353-2364.

Teal, J.M., Weishar, L., 2005. Ecological engineering, adaptive management, and restoration management in Delaware Bay salt marsh restoration. Ecol. Eng. 25, 304-314.

Topping, C.J., Sunderland, K.D., 1992. Limitations to the use of pitfall traps in ecological studies exemplified by a study of spiders in a field of winter wheat. J. Appl. Ecol. 29, 485-491.

Varet, M., Burel, F., Lafage, D., Pétillon, J., 2013. Age-dependent colonization of urban habitats: a diachronic approach using carabid beetles and spiders. Anim. Biol. 63, 257259.

Wolters, M., Garbutt, A., Bakker, J.P., 2005. Plant colonization after managed realignment: the relative importance of diaspore dispersal. J. Appl. Ecol. 42, 770-777.

Zedler, J.B., Lindig-Cisneros, R., 2000. Functional equivalency of restored and natural salt marshes, in: Weinstein, M.P., Kreeger, D.A. (Eds.), Concepts and controversies in tidal marsh ecology. Kluwer Academic Publishing, Dordrecht, pp. 565-582. 


\section{Figure captions}

Fig. 1. Fraction of spider species pool that have colonized realigned saltmarshes in relation to the time since restoration; managed realignment sites (grey circles), accidentally realigned sites (black circles). The fraction of the species pool was calculated for the species richness of all species (a) and that of halophilic species (b); and number of individuals of all species (c) and that of halophilic species (d). The box plot shows the percentage of species found on reference sites $(n=90)$.

Fig. 2. Fraction of spider population pool that have colonized realigned saltmarshes in relation to the time since restoration; managed realignment sites (grey circles), accidentally realigned sites (black circles). The fraction of population pool was calculated for the activity-density of Pirata piraticus (a) Pardosa prativaga (b) and Pardosa purbeckensis (c). The box plot shows the percentage of species found on reference sites $(n=90)$.

Fig. 3. Comparisons of total number of individuals per guild and habitat characteristics among classes of habitat. (a): phytophagous arthropods, (b) polyphagous arthropods, (c) predator arthropods, (d) detrivorous arthropods, (e) vegetation height and (f) litter depth. Different successive letters indicate significant differences among means (Bonferroni post-hoc tests following GLM for phytophagous arthropods and GLMMs for other parameters).

Fig. 4. Comparisons of total number of amphipods among classes of habitat. Different successive letters indicate significant differences among means (Bonferroni post-hoc tests following GLMMs). 

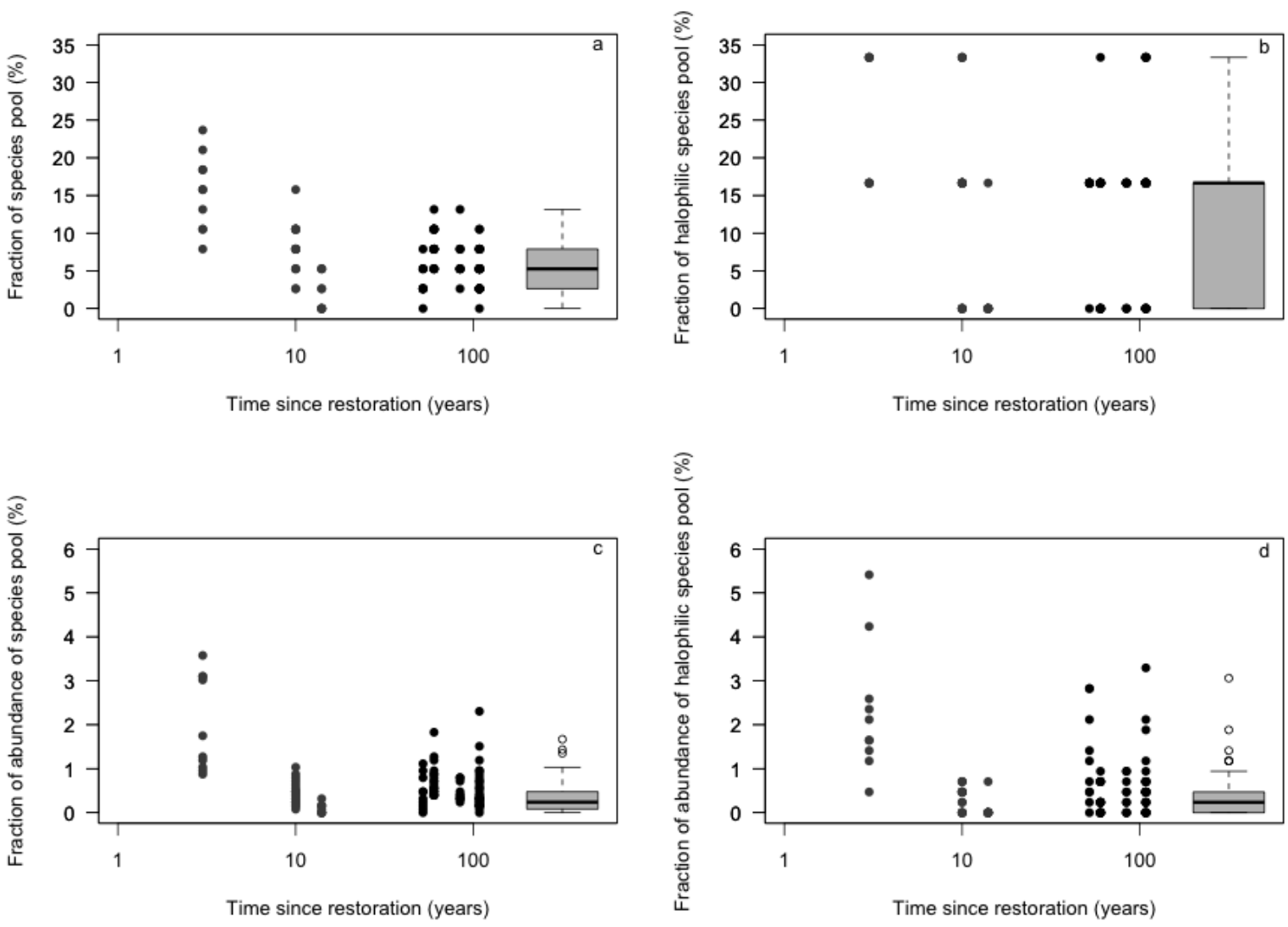

Figure 1. Pétillon et al. 

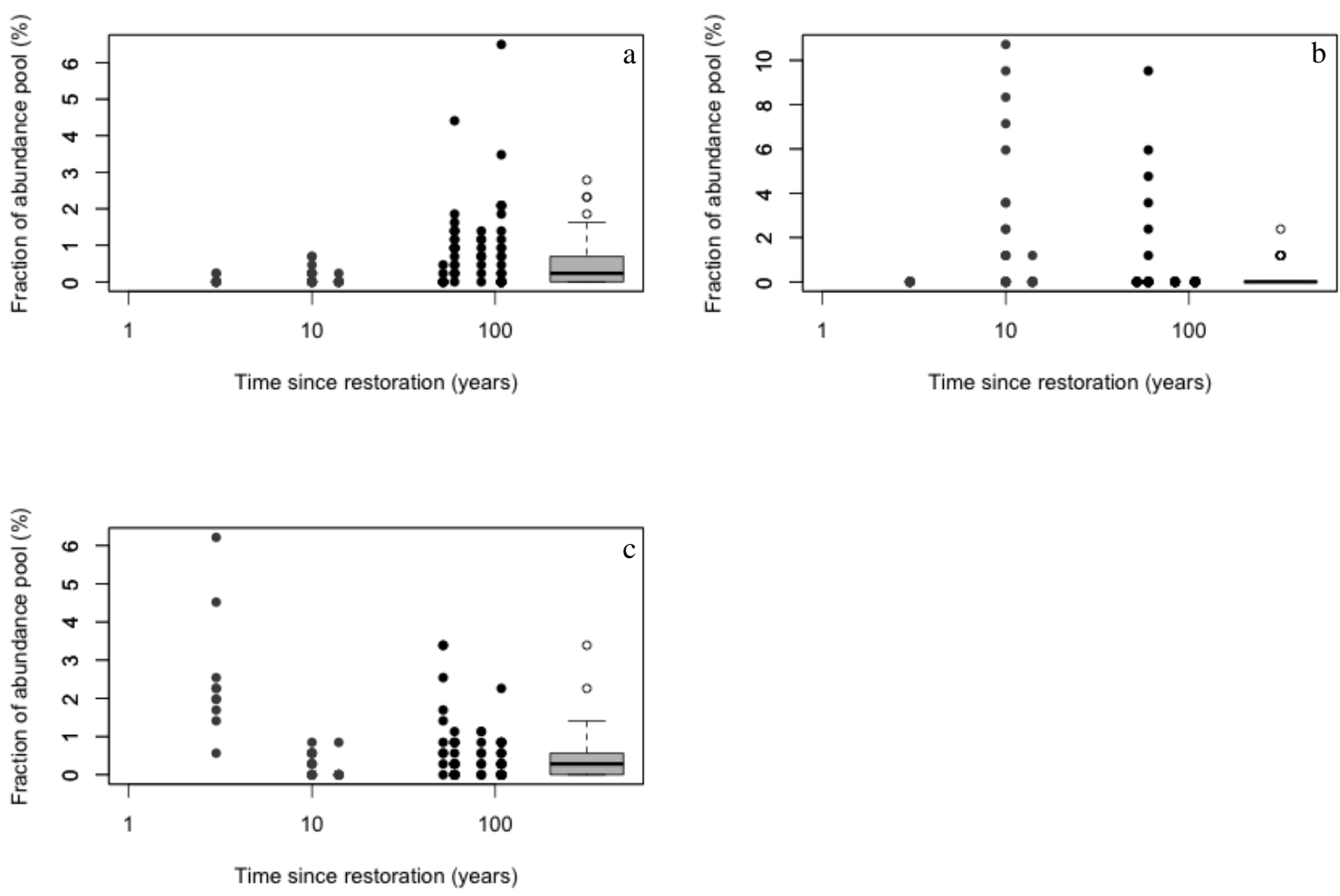

Figure 2. Pétillon et al. 
(a)

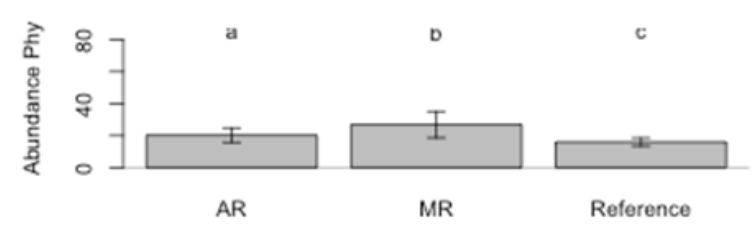

(c)

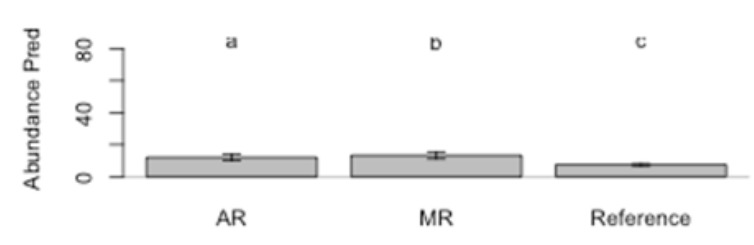

(e)

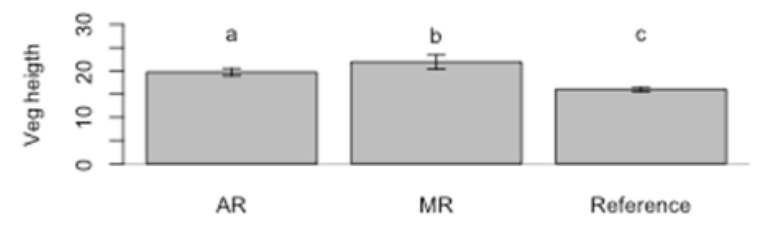

(b)

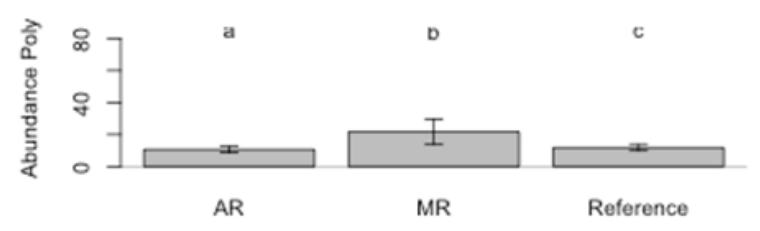

(d)

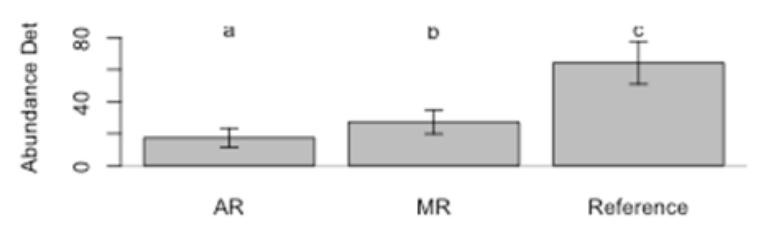

(f)

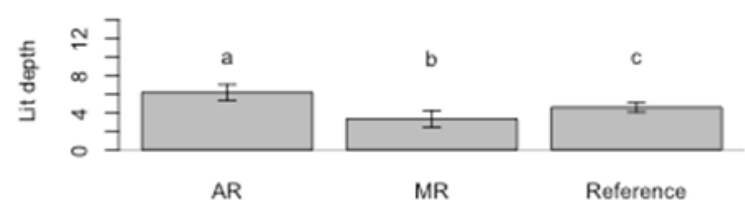

Figure 3. Pétillon et al. 
c
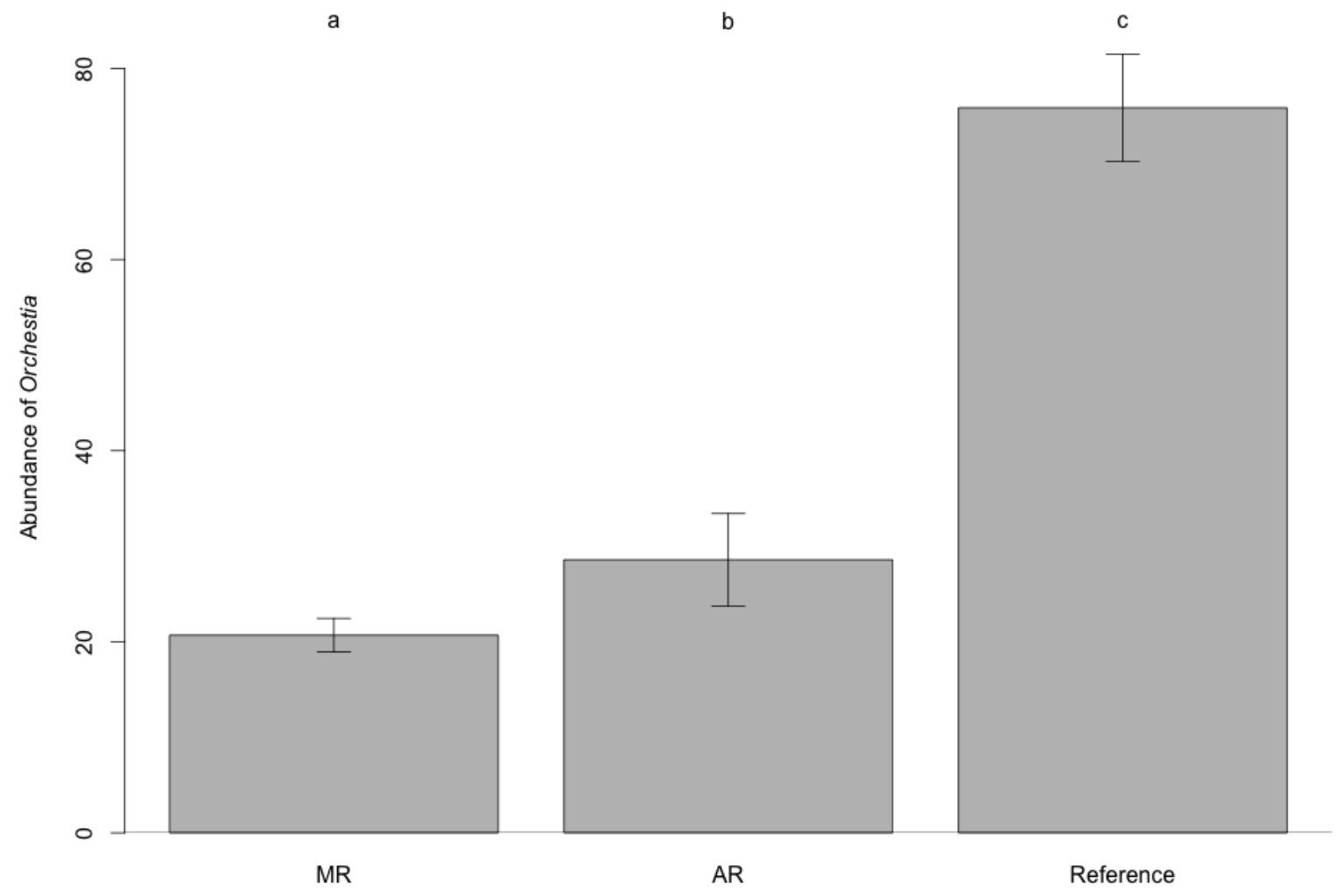

Figure 4. Pétillon et al. 